\title{
Analysis and Performance Evaluation of Microbial Fuel Cells for Electricity Generation
}

\author{
${ }^{1}$ OYEJIDE, JO; ${ }^{* 2}$ ORHORHORO, EK; ${ }^{3}$ SALISU, S. \\ ${ }^{I}$ Department of Mechanical Engineering, Federal University of Petroleum Resources, Effurun, Nigeria. Email: Oyejide.joel@fupre.edu.ng \\ ${ }^{2}$ Department of Mechanical Engineering, College of Engineering, Igbinedion University, Okada, Nigeria. \\ Email: ejiroghene.orhorhoro@iuokada.edu.ng \\ ${ }^{3}$ Department of Mechanical Engineering, Petroleum Training Institute, Effurun, Nigeria.Email: sulaimansalisu@gmail.com \\ *Corresponding author: ejiroghene.orhorhoro@iuokada.edu.ng; +2348064699781
}

\begin{abstract}
This research work is focused on the analysis and performance evaluation of microbial fuel cells (MFCs) consisting of multiple one chamber connected in series and parallels for investigation of electricity generation. Using six units (i.e., unit $\mathrm{A}$, unit $\mathrm{B}$, unit $\mathrm{C}$, unit $\mathrm{D}$, unit $\mathrm{E}$, unit $\mathrm{F}$, unit $\mathrm{G}$ and unit $\mathrm{H}$ ) stacked MFCs, the fuel cells were analyzed and evaluated for performance. The results obtained with a single unit microbial fuel cells show that, unit (A) produced an average power of $0.224 \mathrm{~mW}$, unit (B) an average power of $0.179 \mathrm{~mW}$, unit (C) an average power of $0.138 \mathrm{~mW}$, unit (D) an average power of $0.092 \mathrm{~mW}$, unit (E) an average power of $0.058 \mathrm{~mW}$, unit (F) an average power of $0.036 \mathrm{~mW}$, unit $(\mathrm{G})$ an average power of $0.018 \mathrm{~mW}$, and unit $(\mathrm{H})$ an average power of $0.005 \mathrm{~mW}$. It was observed that decrease in number of microbial fuel cells lead to a corresponding decrease in voltage and current generated, thus drop in power. Conversely, when the unit microbial fuel cells were connected together in series and parallel, improvement in power generation was recorded. An average power of $2.681 \mathrm{~mW}$ and $2.572 \mathrm{~mW}$ were obtained from series and parallel connection respectively.
\end{abstract}

\section{DOI: $\underline{\text { https://dx.doi.org/10.4314/jasem.v22i7.5 }}$}

Copyright: Copyright () 2018 Oyejide, et al. This is an open access article distributed under the Creative Commons Attribution License (CCL), which permits unrestricted use, distribution, and reproduction in any medium, provided the original work is properly cited.

Dates: Received: 29 April 2018; Revised: 14 May: 2018; Accepted: 06 June 2018

Keywords: Microbial fuel cells, anode, cathode, power, renewable energy, electricity generation

As a result of unavailability and rapidly increase in costs of energy supply couple with waste disposal and increasing public concerns with eco-friendly environmental, conversion of biodegradable waste to energy is becoming a more economically viable practice (Orhorhoro et al., 2017a), (Orhorhoro et al., (2017b). Generally, energy sources can be classified into renewable energy source and non-renewable energy source (Akdeniz et al., 2002). Non-renewable energy sources are group into two major classifications: nuclear and fossil energy (Rahimnejad et al., 2009). Fossil fuel has negative effect on our ecosystem owing to the emission of carbon dioxide (Orhorhoro et al., 2016a), (Orhorhoro et al., 2016b). Consumption of fossil fuels has severely imperiled human life through its drastic aftermaths, such as global warming and atmospheric pollution (Tardast $e t$ al., 2012). Due to the hazard recorded from nonrenewable energy source, the world attention is now on renewable energy sources such as biofuel, solar, wind, hydro, etc. that are environmental friedly (Zhou et al., 2013).

However, one of the recently proposed alternative energy sources is the microbial fuel cells (MFCs).
MFCs have gained much recognition because of its power generation potential from biodegradable organic waste (Lewis, 1996). MFCs are of numerous advantages over other kinds of energy generators. For example; there is no emission of environmental polluting gases such as oxide from sulphur, carbon, nitrogen (i.e., SOx, NOx, $\mathrm{CO}_{2}$ and CO) (Lewis, 1996). MFCs are fuel cells that make use of active microorganism as a biocatalyst in an anaerobic anode compartment for production of bioelectricity (Rahimnejad et al., 2011), (Zhou et al., 2012). MFCs generate electricity directly from various biodegradable organic wastes through microbial release of electrons to an electrode. MFCs can also be used to recover energy from wastewater, while in the process eliminating the need for wastewater aeration and reducing sludge production (Hassan et al., 2014).

Typical microbial fuel cells (Fig. 1) consist of anode and cathode compartments physically separated by a proton exchange membrane (PEM) (Rahimnejad et al., 2012). Active biocatalyst in the anode oxidizes the biodegradable organic substrates and produces electrons and protons (Jana et al., 2013). The protons are conducted to the cathode chamber through the 
proton exchange membrane, and the electrons are conveyed through the external circuit (Ghasemi et al., 2015). The active biocatalyst in the anode compartment oxidizes the carbon substrates, and generates electrons and protons. Electrons and protons are consumed in the cathode compartment, combining with oxygen to form water (Jana et al., 2013). However, oxygen in the anode chamber inhibits the production of bio-electricity. For this reason, a pragmatic system must be design to keep the bacteria separated from oxygen (anaerobic chamber for anodic reaction) (Kim et al., 2008). Equation 1 and equation 2 show anodic reaction of acetic acid.

$\mathrm{C}_{2} \mathrm{H}_{4} \mathrm{O}_{2}(\mathrm{~s})+2 \mathrm{H}_{2} \mathrm{O} \rightarrow \mathrm{CO}_{2}(\mathrm{~g})+8 \mathrm{e}^{-}+8 \mathrm{H}^{+}$

$2 \mathrm{O}_{2}(\mathrm{~g})+8 \mathrm{H}^{+}+8 \mathrm{e}^{-} \rightarrow 4 \mathrm{H}_{2} \mathrm{O}(\mathrm{l})$

The performance of MFCs is affected by several factors such as (Rabaey et al., 2006); Supply and consumption of oxygen in cathode chamber; Oxidation of substrates in anode chamber; Electron shuttle from anode compartment to anode surface; and Permeability of proton exchange membrane

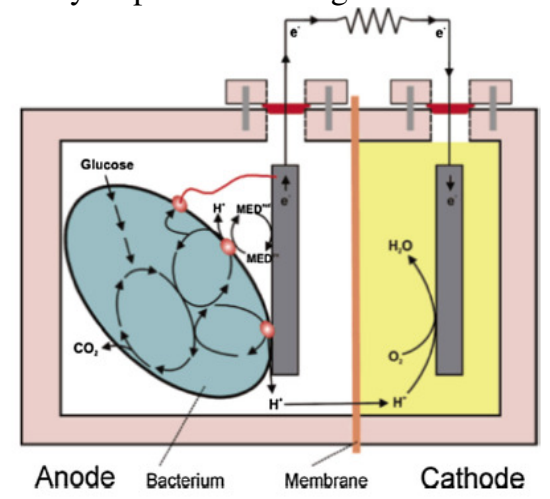

Fig. 1: MFCs system with anode and cathode compartments (Rahimnejad et al., 2012).

MFCs have various practical applications ranging from breweries, domestic wastewater treatment (black water, water from abattoir etc.), desalination plants, hydrogen production, remote sensing, and pollution remediation, etc. (Lewis, 1996), (Zhou et al., 2013). Widespread use of MFCs in these areas can help in converting biodegradable organic waste into useful energy thereby making our environment healthy (Mehmood et al., 2009), (Sharma, and Li, 2010). Nigeria is a very conducive place for bio-degradable activities because it has a dry and humid climate with average room temperature of $23^{\circ} \mathrm{C}$ and maximum temperature range of $37^{\circ} \mathrm{C}-40^{\circ} \mathrm{C}$ (NESP, 2015). Nigeria has a large population that make bio-waste readily available with a very good number of this population suffering poor electricity supply, therefore, we envisage a time where every household harness the electrical energy potentials of a microbial fuel cell. In this research work, analysis and performance evaluation of microbial fuel cells for electricity generation was investigated.

\section{MATERIALS AND METHOD}

MFCs consisting of one multiple chambers connected in series and parallels were used in this research work. The key to this choice is mainly to increase voltage and reduce spaces occupied by the MFCs. The MFCs were incorporated with graphite electrode for the anode and zinc electrode for the cathode, for transferring electrons. The anode is the positive terminal where the electrons were deposited and transferred by bacteria as electrons got generated. The cathode is the negative terminal where electrons are transferred from the anode. The buildup of electrons in anode caused the potential difference between the two electrodes, so that the electrons could flow from anode to cathode thereby generating electricity. Also, the electrodes were connected in parallel in order to increase its surface area thereby increasing current. Six units (i.e., unit $\mathrm{A}$, unit $\mathrm{B}$, unit $\mathrm{C}$, unit $\mathrm{D}$, unit $\mathrm{E}$, Unit F, and Unit G) stacked microbial fuel cells were used for the analysis and performance evaluation. Unit A contained 16 microbial fuel cells of $60 \mathrm{cl}$ each, connected in series, unit B contained 14 microbial fuel cells of $60 \mathrm{cl}$ each connected in series, unit $\mathrm{C}$ contained 10 microbial fuel cells of $60 \mathrm{cl}$ each connected in series, unit D contained 8 microbial fuel cells of $60 \mathrm{cl}$ each connected in series, unit $\mathrm{E}$ contained 6 microbial fuel cells of $60 \mathrm{cl}$ each connected in series, unit $\mathrm{F}$ contained 4 microbial fuel cells of $60 \mathrm{cl}$ each connected in series, unit $\mathrm{G}$ contained 3 microbial fuel cells, and unit $\mathrm{H}$ contained 2 microbial fuel cells of $60 \mathrm{cl}$ each connected in series. Distilled water was poured into the cells and initial readings taken. The water was emptied and the cells were filled with bio-waste and wastewater. Variations in $\mathrm{pH}$, voltage, currents were monitored and recorded. The same substrates composition was used throughout this research work.

\section{RESULTS AND DISCUSSION}

The results obtained after twelve (12) days on unit Aunit $\mathrm{G}$ single are shown in Table 1-Table 6. Table 5 present the combined results of all the units connected together in series and parallels. Unit A contained 16 microbial fuel cells of $60 \mathrm{cl}$ each, connected in series. It was observed that as the $\mathrm{pH}$ gradually moves towards neutrality, drop in voltage, current and power readings were recorded. Improve currents and voltage were recorded when the $\mathrm{pH}$ readings were at the acidic and alkaline medium. Average voltage reading of $0.51 \mathrm{~V}$, and an average current reading of $0.44 \mathrm{~mA}$ were obtained. These values were used to determine the power which was obtained as $0.224 \mathrm{~mW}$. 
Table 1: Unit (A) Single Chamber Fuel Cell

\begin{tabular}{lllll}
\hline Day & $\mathbf{p H}$ & $\begin{array}{l}\text { Voltage } \\
(\mathbf{V})\end{array}$ & $\begin{array}{l}\text { Current } \\
(\mathbf{m A})\end{array}$ & $\begin{array}{l}\text { Power } \\
\left.\mathbf{( 1 0}^{-3} \mathbf{W}\right)\end{array}$ \\
\hline 1 & 5.8 & 0.69 & 0.64 & 0.442 \\
2 & 5.9 & 0.66 & 0.60 & 0.396 \\
3 & 5.9 & 0.65 & 0.59 & 0.384 \\
4 & 6.0 & 0.63 & 0.54 & 0.340 \\
5 & 6.1 & 0.60 & 0.50 & 0.300 \\
6 & 6.3 & 0.56 & 0.49 & 0.274 \\
7 & 6.4 & 0.53 & 0.44 & 0.233 \\
8 & 6.6 & 0.52 & 0.41 & 0.213 \\
9 & 9.4 & 0.54 & 0.49 & 0.265 \\
10 & 8.3 & 0.44 & 0.42 & 0.185 \\
11 & 7.8 & 0.18 & 0.10 & 0.018 \\
12 & 7.6 & 0.13 & 0.09 & 0.012 \\
$\sum$ & 82.1 & 6.13 & 5.31 & 2.688 \\
$\mathrm{~A}$ & 6.84 & 0.51 & 0.44 & 0.224 \\
\hline
\end{tabular}

Table 2: Unit (B) Single Chamber Fuel Cell

\begin{tabular}{lllll}
\hline Day & $\mathrm{pH}$ & $\begin{array}{l}\text { Voltage } \\
(\mathrm{V})\end{array}$ & $\begin{array}{l}\text { Current } \\
(\mathrm{mA})\end{array}$ & $\begin{array}{l}\text { Power } \\
\left(10^{-3} \mathrm{~W}\right)\end{array}$ \\
\hline 1 & 5.8 & 0.65 & 0.56 & 0.364 \\
2 & 5.9 & 0.62 & 0.52 & 0.322 \\
3 & 5.9 & 0.61 & 0.50 & 0.305 \\
4 & 6.0 & 0.59 & 0.48 & 0.283 \\
5 & 6.1 & 0.56 & 0.43 & 0.241 \\
6 & 6.3 & 0.52 & 0.42 & 0.218 \\
7 & 6.4 & 0.49 & 0.38 & 0.186 \\
8 & 6.6 & 0.48 & 0.35 & 0.168 \\
9 & 9.4 & 0.50 & 0.41 & 0.205 \\
10 & 8.3 & 0.40 & 0.35 & 0.140 \\
11 & 7.8 & 0.14 & 0.09 & 0.013 \\
12 & 7.6 & 0.10 & 0.07 & 0.007 \\
$\sum$ & 82.1 & 5.66 & 4.56 & 2.148 \\
$\mathrm{~A}$ & 6.84 & 0.47 & 0.38 & 0.179 \\
\hline
\end{tabular}

Table 3: Unit C Single Chamber Fuel Cell

\begin{tabular}{lllll}
\hline Day & $\mathbf{p H}$ & $\begin{array}{l}\text { Voltage } \\
(\mathbf{V})\end{array}$ & $\begin{array}{l}\text { Current } \\
(\mathbf{m A})\end{array}$ & $\begin{array}{l}\text { Power } \\
(\mathbf{1 0}-\mathbf{3} \mathbf{~})\end{array}$ \\
\hline 1 & 5.8 & 0.60 & 0.52 & 0.312 \\
2 & 5.9 & 0.56 & 0.46 & 0.258 \\
3 & 5.9 & 0.54 & 0.45 & 0.243 \\
4 & 6.0 & 0.53 & 0.43 & 0.228 \\
5 & 6.1 & 0.50 & 0.39 & 0.195 \\
6 & 6.3 & 0.46 & 0.37 & 0.170 \\
7 & 6.4 & 0.44 & 0.35 & 0.154 \\
8 & 6.6 & 0.42 & 0.33 & 0.139 \\
9 & 9.4 & 0.40 & 0.31 & 0.124 \\
& & & & \\
10 & 8.3 & 0.38 & 0.28 & 0.106 \\
11 & 7.8 & 0.10 & 0.05 & 0.005 \\
12 & 7.6 & 0.07 & 0.03 & 0.002 \\
$\sum$ & 82.1 & 5.00 & 3.97 & 1.656 \\
$\mathrm{~A}$ & 6.84 & 0.417 & 0.331 & 0.138 \\
\hline
\end{tabular}

The gradual drops in voltage and current were due to increase in bacteria activity at the anode. The bacteria form a bio-film at the anode and as the bacteria food decreases, some of the bacteria die leading to the decrease in the voltage produced (Rahimnejad et al., 2009). The $\mathrm{pH}$ concentration of the substrate was lowest on the first day and highest on the $9^{\text {th }}$ day (Table1), and this was due to fermentation of the substrate which involves breaking down of long chain fatty acid to acetic acid (Orhorhoro et al., 2017a). The current produced is directly proportional to the voltage, and power. The $\mathrm{pH}$, voltage, current, and power generated from unit B microbial fuel cell is shown in Table 2.

Unit B contained 14 microbial fuel cells of $60 \mathrm{cl}$ each connected in series. As reported with unit A, the power, currents and voltages produced in the duration of twelve days depend on the rate of hydrolysis and fermentation taking place in the system. Low values and high values of $\mathrm{pH}$ readings favored voltage, and current generation, thus improved power. However, unlike in unit A, the power, current, and voltage generated were low and this was as a result of reduced number of microbial fuel cell. The trends follow the same pattern for unit $\mathrm{C}$, unit $\mathrm{D}$, unit $\mathrm{E}$, unit $\mathrm{F}$, unit $\mathrm{G}$, and unit $\mathrm{H}$.

It was observed that the higher the number of microbial fuel cells, the higher the voltages, currents and power generated. For unit B microbial fuel cell, an average voltage, current and power of 0.47 volts, $0.38 \mathrm{~mA}$, and $0.179 \mathrm{mw}$ were obtained. Table 3 shows the results obtained with unit $\mathrm{C}$ microbial fuel cell. Unit $C$ contained 10 microbial fuel cells of $60 \mathrm{cl}$ plastic bottle each connected in series. The results obtained showed a linear relationship between voltages, current and power. An average voltage of 0.417 volts, current of $0.331 \mathrm{~mA}$, and power of $0.138 \mathrm{mw}$ were obtained. There was gradual drop in voltage, current and power readings as the process progresses.

This changes in current, voltage, and power go in line with unit (A) and unit B microbial fuel cells. However, the average values of voltage, current and power obtained were lower than unit A and unit B. This process was repeated for unit $\mathrm{D}$ that comprises of 8 microbial fuel cells; unit $\mathrm{E}$ that comprises of 6 microbial fuel cells; unit $\mathrm{F}$ that comprises of 4 microbial fuel cells; unit $G$ that comprises of 3 microbial fuel cells; and unit $\mathrm{H}$ that comprises of 2 microbial fuel cells. The summary of results obtained is shown in Table 4.

There was a continuous decrease in average voltage, average current and average power as the number of microbial fuel cells connected in series decrease from $16 \mathrm{MFCs}$ to $2 \mathrm{MFCs}$. However, to generate optimum power, all the units (i.e., unit A-unit $\mathrm{H}$ ) were connected both in parallel and series. The parallel connection of all the unit cells improves the currents while the series connection improves the voltage (Table 5). 
Table 4: Summary of Results obtained with Unit (A)-Unit (H) Single Chamber Fuel Cell

\begin{tabular}{llllc}
\hline Cell connections & $\begin{array}{c}\text { Average } \\
\mathbf{~ p H}\end{array}$ & $\begin{array}{l}\text { Average } \\
\text { Voltage (V) }\end{array}$ & $\begin{array}{l}\text { Average } \\
\text { Current (mA) }\end{array}$ & $\begin{array}{c}\text { Average } \\
\text { Power (mw) }\end{array}$ \\
\hline Series connection of 16 MFCs (Unit A) & 6.84 & 0.510 & 0.440 & 0.224 \\
Series connection of 14 MFCs (Unit B) & 6.84 & 0.470 & 0.380 & 0.179 \\
Series connection of 10 MFCs (Unit C) & 6.84 & 0.417 & 0.331 & 0.138 \\
Series connection of 8 MFCs (Unit D) & 6.84 & 0.366 & 0.251 & 0.092 \\
Series connection of 6 MFCs (Unit E) & 6.84 & 0.318 & 0.183 & 0.058 \\
Series connection of 4 MFCs (Unit F) & 6.84 & 0.266 & 0.134 & 0.036 \\
Series connection of 3 MFCs (Unit G) & 6.84 & 0.215 & 0.084 & 0.018 \\
Series connection of 2 MFCs (Unit H) & 6.84 & 0.167 & 0.035 & 0.005 \\
\hline
\end{tabular}

Table 5: Summary of Results obtained with Unit (A)-Unit (H) Stacked Microbial Fuel Cell

\begin{tabular}{llll}
\hline Cell connections & $\begin{array}{l}\text { Average } \\
\text { Voltage }(\mathbf{V})\end{array}$ & $\begin{array}{l}\text { Current } \\
(\mathbf{m A})\end{array}$ & $\begin{array}{l}\text { Average } \\
\text { Power }(\mathbf{m w})\end{array}$ \\
\hline Series connection of all units (A-H) & 2.654 & 1.010 & 2.681 \\
Parallel connection of all units (A-H) & 1.425 & 1.805 & 2.572 \\
\hline
\end{tabular}

Conclusion: This research work is focused on the analysis and performance evaluation of microbial fuel cells. The results obtained with a single unit microbial fuel cells show that, unit (A) produced an average power of $0.224 \mathrm{~mW}$, unit (B) an average power of $0.179 \mathrm{~mW}$, unit (C) an average power of $0.138 \mathrm{~mW}$, unit (D) an average power of $0.092 \mathrm{~mW}$, unit (E) an average power of $0.058 \mathrm{~mW}$, unit $(\mathrm{F})$ an average power of $0.036 \mathrm{~mW}$, unit $(\mathrm{G})$ an average power of $0.018 \mathrm{~mW}$, and unit $(\mathrm{H})$ an average power of $0.005 \mathrm{~mW}$. It was observed that a decrease in number of microbial fuel cells lead to a corresponding decrease in voltage and current generated, thus drop in power. Conversely, when the unit microbial fuel cells were connected in series and parallel, improvement in power generated was recorded. An average power of $2.681 \mathrm{~mW}$ and $2.572 \mathrm{~mW}$ were obtained from series and parallel connection respectively. Therefore, for optimum power generation, currents and voltages can be increased by connecting several microbial fuel cells in parallel and in series respectively.

\section{REFERENCES}

Akdeniz F; Caglar A; Gullu D (2002). Recent energy investigations on fossil and alternative non fossil resources in Turke. Energy Convers Manage, 43:575-589

Ghasemi M; Wan WR; Ismail WR; Rahimnejad M; Ismail AF; Leong JX; Miskan M; Ben LK (2012). Effect of pretreatment and biofouling of proton exchange membrane on microbial fuel cell performance. Int. J. Hydrogen Energy 38: 54805484

Hassan SH; El-Rab S; Rahimnejad M; Ghasemi M; Joo J; Ok Y; Kim I; Oh S (2014). Electricity generation from rice straw using a microbial fuel cell. Int. J. Hydro. Eng, (39): 9490-9496
Jana PS; Behera M; Ghangrekar MM (2012). Performance comparison of up-flow microbial fuel cells fabricated using proton exchange membrane and earthen cylinder. Int. J. Hydrogen Energy, (35): 5681-5686

Khan MR; Karim MR; Amin MSA (2012). Generation of Bio-electricity by Microbial Fuel

Cells. International Journal of Engineering and Technology, 1 (3): 231-237

Kim JR; Dec J; Bruns MA; Logan BE (2008). Removal of odors from swine wastewater by using microbial fuel cells, Appl. Environ. Microb, 74: $2540-2543$

Lewis K (1966). Symposium on bioelectrochemistry of microorganisms. Biochemical fuel cells Bacteriol. Rev. 30:101-113

Mehmood M; Adetutu E; Nedwell D; Ball A; (2009). Microbial treatment of landfill leachate using aerated lagoons. Biores. Technol. 100:2741-2744

Orhorhoro EK; Ebunilo PO; Tamuno RI; Essienubong AI. (2016a). The Study of Anaerobic CoDigestion of Non-Uniform Multiple Feed Stock Availability and Composition in Nigeria. Euro. $J$. Engineer. Res. Sci. 1(1), 39-42

Orhorhoro EK; Orhorhoro OW; Ikpe AE (2016b). A Study of Solar Energy Potential in Sapele, Nigeria. Int. J. of Therm. Environ. Engineer. 13(2):129-133

Orhorhoro EK; Ebunilo PO; Sadjere EG; (2017a). Development of a Predictive Model for

Biogas Yield Using Artificial Neural Networks (ANNs) Approach. Amer. J. Energy. Power. Engineer. 4 (6): 71-77 
Orhorhoro EK; Ebunilo PO; Sadjere EG; (2017b). Experimental Determination of Effect of Total Solid (TS) and Volatile Solid (VS) on Biogas Yield. Amer. J. Modern Energy, 3(6): 131-135

Rabaey K; Van de SK; Maignien L; Boon N; Aelterman P; Clauwaert P; De Schamphelaire L; Pham HT; Vermeulen J; Verhaege M (2006). Microbial fuel cells for sulfide removal, Environ. Sci. Technol. 40: 5218-5224

Rahimnejad M; Ghasemi M; Najafpour GD; Ghoreyshi A; Bakeri G; Hassaninejad K; Talebnia F (2012). Acetone removal and bioelectricity generation in dual chamber Microbial Fuel Cell, Am. J. Biochem. Biotech, (8):304-310

Rahimnejad M; Ghoreyshi AA; Najafpour G; Jafary T (2011). Power generation from organic substrate in batch and continuous flow microbial fuel cell operations. Appl. Energy, 88:3999-4004

Rahimneja M; Mokhtarian N; Najafpour G; Ghoreyshi A; Dahud W (2009). Effective parameters on performance of microbial fuel cell. IEEE, 411415
Sharma Y; Li B (2010). The variation of power generation with organic substrates in singlechamber microbial fuel cell (SCMFCs), Bioresource Technol, 101: 1844-1850

Zhou M; Jin T; Wu Z; Chi M; Gu T (2012). Microbial fuel cells for bioenergy and bioproducts. Sustainable Bioenergy and Bioproducts, Springer, 131-171

Zhou M; Yang J; Wang H; Jin T; Hassett DJ; Gu T (2013). Bioelectrochemistry of microbial fuel cells and their potential applications in bioenergy, Bioenergy Research: Adv. Appl. 131-153

Tardast A; Rahimnejad M; Najafpour G; Ghoreyshi AA; Zare H (2012). Fabrication and operation of a novel membrane-less microbial fuel cell as a bioelectricity generator. Int. J. Environ Engr., $3: 1-5$

The Nigerian Energy Support Programme, NESP, (2015). The Nigeria Energy Sector-An Overview with a Special Emphasis on Renewable Energy: Energy Efficiency and Rural Electrification. Federal Ministry of Power, Abuja, 2nd edition, 24-28 